\title{
COMPARATIVE ANALYSIS ON IMMUNITY OF VOLLEYBALL PLAYERS BEFORE AND AFTER TAKING GRAPE PROCYANIDINS SPORTS SUPPLEMENT
}

\section{ANÁLISIS COMPARATIVO DE LA FUNCIÓN DE INMUNODEFICIENCIA DEL VOLEIBOL UTILIZADO POREL SUPLEMENTO DEPORTIVO VITRO VEGETARIANO}

\section{Xiaojun Tang 1 (ID (Public Health) \\ Mingang Guo' (D) \\ (Basic Medicine) \\ 1. Department of Physical Education, Wuhan University of Technology, Wuhan 430070, Hubei, China.}

\section{Correspondence:}

Wuhan 430070, Hubei, China.zn709155@21cn.com; It723931@21cn.com

\begin{abstract}
Grape proanthocyanidin is a good health product, without side effects and excellent biological activity, but research in the field of sports tonic is still relatively slow. Currently, the technology of preparation and extraction of grape proanthocyanidins is relatively mature. This fact laid the groundwork for sports tonic proanthocyanidin research. This study first described the biological structure of proanthocyanidin in grapes, and built the immune system of volleyball players before and after taking proanthocyanidin sports supplements. He then analyzed the factors that influence immunity. The results show that the primary index subsystem is consistent with the total system in each phase, but there are still few differences over time, which can be divided into four phases: development, recession, recovery and stability; at the level of scientific training it is reasonable. Male and female athletes take exercise supplements containing proanthocyanidin at each level of training. Regarding humoral immunity and cellular immunity, there was no adverse reaction. This study may offer some reference value for other athletes before and after taking proanthocyanidin as a sports supplement.
\end{abstract}

Keywords: grape proanthocyanidin; immunity; supplements; athletes.

\section{RESUMO}

A proantocianidina da uva éum produto bom para a saúde, sem efeitos colaterais e excelente atividade biológica, mas a pesquisa no campo do tônico esportivo ainda é relativamente lenta. Atualmente, a tecnologia de preparação e extração das proantocianidinas de uva está relativamente madura. Este fato lançou as bases para a investigação da proantocianidina desportiva tónica. Este estudo descreveu, em primeiro lugar, a estrutura biológica da proantocianidina das uvas, e construiu o sistema imunitário dos jogadores de voleibol antes e depois de tomar suplementos desportivos de proantocianidina. Em seguida analisou os fatores que influenciam a imunidade. Os resultados mostram que o subsistema de indice primário é coerente com o sistema total em cada fase, mas ainda há poucas diferenças no tempo, que podem ser divididas em quatro fases: desenvolvimento, recessão, recuperação e estabilidade; no plano de formação científico e razoável. Os atletas do sexo masculino e feminino tomam suplementos de exercício contendo proantocianidina em cada estágio de treinamento. Com respeito à imunidade humoral e à imunidade celular não houve reação adversa. Este estudo pode oferecer algum valor de referência para outros atletas antes e depois de tomar proantocianidina como suplemento desportivo.

Descritores: proantocianidina de uva; imunidade; suplementos; atletas.

\section{RESUMEN}

La proantocianidina de la uva es un producto bueno para la salud, sin efectos colaterales y excelente actividad biológica, pero la investigación en el campo del tónico deportivo aun es relativamente lenta. Actualmente, la tecnología de preparación y extracción de las proantocianidinas de uva está relativamente madura. Este hecho lanzó las bases para la investigación de la proantocianidina deportiva tónica. Este estudio describió, en primer lugar, la estructura biológica de la proantocianidina de las uvas, y construyó el sistema inmunitario de los jugadores de voleibol antes y después de tomar suplementos deportivos de proantocianidina. Enseguida analizó los factores que influencian la inmunidad. Los resultados muestran que el subsistema de índice primario es coherente con el sistema total en cada fase, pero aun hay pocas diferencias en el tiempo, que pueden ser divididas en cuatro fases: desarrollo, recesión, recuperación y estabilidad; en el plano de la formación científica es razonable. Los atletas del sexo masculino y femenino toman suplementos de ejercicio conteniendo proantocianidina en cada nivel de entrenamiento. Con respecto a la inmunidad humoral y a la inmunidad celular no hubo reacción adversa. Este estudio puede ofrecer algún valor de referencia para otros atletas antes y después de tomar proantocianidina como suplemento deportivo.

Descriptores: proantocianidina de uva; inmunidad; suplementos; atletas. 


\section{INTRODUCTION}

Procyanidins (PCS) is a representative plant polyphenol mixture in nature, which can be extracted from hawthorn, ginkgo, grape and other plants. ${ }^{1}$ In grape, the purity of procyanidin extracted by people is high. It is found that the main components of procyanidin are catechin, epicatechin and catechin gallic acid. ${ }^{2}$ It has been pointed out that the main components of procyanidin also include organic acids mainly composed of caffeic acid, which are combined by synergistic polymerization to present various bioactive functions. ${ }^{3}$ Grape proanthocyanins have good effects in anti-aging, anti-tumor, anti fatigue, immunity regulation, antioxidant activity, neuron protection, free radical removal, cardiovascular disease and other aspects. According to the previous volleyball players' experience, if we want to stimulate the body enough, we must have high-intensity sports training to effectively improve the sports performance. ${ }^{4}$ But long term high-intensity sports training will have a negative impact on the athletes' body, thus reducing the immunity of athletes. In order to continuously improve the athletes' competitive level, the training intensity and physical state of athletes must be kept consistent for a long time. Therefore, athletes should adjust the body exercise supplement in addition to balancing the diet to maintain energy and nutrition intake. ${ }^{5}$ Therefore, in this study, the volleyball players take the grape proanthocyanin sports supplement, apply scientific sports training mode, choose the appropriate intensity of exercise, and compare the cellular and humoral immunity levels of the athletes.

In view of the problems of volleyball players'immunity before and after taking grape proanthocyanidins, the analytic method of combining analytic hierarchy process with statistics and comparative analysis is adopted. Among them, the coefficient of variation mainly reflects the relative fluctuation degree between data, and can eliminate the influence of mean or unit on the degree of data variation, so as to delete it in the research process R-cluster analysis method can not only understand the degree of familiarization among groups, but also judge the degree of intimacy among individuals in the group, and it should be used for regional division to find the similarity between regions.

The innovation of this study is to apply AHP with statistical and comparative analysis methods. Finally, two primary indicators are obtained, namely humoral immunity level (B1) and cellular immunity level (B2); there are 7 secondary indicators, namely human serum $\lg A(C 1), \operatorname{lgG}(C 2), \lg M$ (C3), white blood cell (C4), neutrophil (C5), lymphocyte (C6), monocyte (C7). The second level indicators C $1-C 3$ and C4-C7 are responsible for the first level indicators B1 and B2 respectively, and there is no relationship among the groups, which is an incomplete hierarchical model.

\section{RELATED WORK}

In recent years, the research of grape proanthocyanidins in athletes' nutritional supplements has been highly valued by many relevant professionals, and researchers at home and abroad have also conducted in-depth research on this technology. Feij et al. Observed the repair effect of grape polyphenols on radiation damage of hematopoietic system in mice irradiated with 60Co - $\gamma$ - ray. Results compared with the normal control group, the spleen coefficient, the number of bone marrow nucleated cells, the number of peripheral blood leukocytes and DNA content of bone marrow cells in the irradiation control group were significantly decreased $(P<0.05)$, and the number of splenic nodules was significantly increased $(P<0.05) .{ }^{6}$ Fang l et al. Studied the effects of grape seed proanthocyanidins (GSP) on growth performance, digestive enzyme activity, antioxidant enzyme activity and mRNA expression of weaned piglets. Studies have shown that low and medium dietary GSP supplementation can improve the growth performance of weaned piglets, which is related to the improvement of digestive and antioxidant enzyme activities and the improvement of piglets' resistance to weaning stress. ${ }^{7}$ Peiyu $Z$ et al. Verified and compared the anti digestion and antioxidant activities of GSP with different DPS, and determined the anti digestion activity of key digestive enzymes. The results showed that high molecular weight procyanidins had the same antioxidant activity and stronger anti digestion effect as low molecular weight procyanidins. ${ }^{8}$
Through the research of grape procyanidins by scholars at home and abroad, we can see that although there is a keen interest in the application, extraction and mechanism of grape procyanidins at home and abroad, the research based on grape proanthocyanidins sports supplements is still a blank state. Therefore, this study conducted in-depth analysis of grape proanthocyanidins in the field of sports supplements, aiming to provide certain reference value in practice and theory for volleyball players'immunity research before and after taking grape procyanidins sports supplement.

\section{COMPARATIVE EVALUATION OF IMMUNITY OF VOLLEYBALL PLAYERS BEFORE AND AFTER TAKING GRAPE PROCYANIDINS SPORTS SUPPLEMENT}

\section{Research materials and preparation methods}

In this study, fresh grapes were selected and dehydrated, and then defatted. The main instruments used are centrifuge (allegrax-15r) produced by Beckman company, rotary dryer (k221a) produced by Shanghai sorbet Instruments Co., Ltd., HPLC (1200) produced by Agilent company, flow cytometer (Canto II) produced by BD company in the United States, and enzyme labeled instrument (elx800) produced by Baote company in the United States. The reagents used were flow cytometer of BD company and human blood Serum lgM, IgG, IgA, indirect ELISA design and ethanol were all analytically pure. In the process of extraction and purification of grape proanthocyanidins, the grape seeds were defatted, and the grape seeds with feed liquid ratio of 1:10 ( $\mathrm{g} / \mathrm{ml}$ ) were mixed in $70 \%$ ethanol, and then extracted. First, the extraction solution was centrifuged at room temperature for $50 \mathrm{~min}$, and then concentrated for three times at a rate of $50 \mathrm{ml}$, and then the extraction solution was concentrated for three times at a rate of $50 \mathrm{ml}$ After purification, two-step process was applied to concentrate the extract to $50 \mathrm{ml}$ and freeze-drying was used to obtain grape proanthocyanidins dry powder; HPLC was used to analyze the obtained products to ensure that the content of grape proanthocyanidins was higher than 99\%.

In order to prepare the sports tonic containing proanthocyanidins, $2.2 \mathrm{mg}$ disodium phosphate, $2.1 \mathrm{mg}$ potassium phosphate, $25 \mathrm{mg}$ starch and $10 \mathrm{mg}$ proanthocyanidins are required. After removing impurities, they are crushed, fully stirred and pressed into tablets. The containers with marks are used for packaging and sealing, and the desiccant is put in. This study selects 20 male and female volleyball players of XX Institute of physical education as an example. The basic information of the players is shown in Table 1.

After the athletes started training, they took exercise supplements containing anthocyanins 3 times a day until the end of the experiment. The training program is based on the training experience outside, and has been modified appropriately, as shown in Table 2.

Table 2. Sports training program.

\begin{tabular}{c|c|c}
\hline Stage & Time and frequency & Training content \\
\hline $\begin{array}{c}\text { The first training } \\
\text { phase }\end{array}$ & 3 weeks, 6 times & $\begin{array}{r}\text { Preparation activities, mainly } \\
\text { stretching, coordination } \\
\text { and strength training }\end{array}$ \\
\hline $\begin{array}{c}\text { The second } \\
\text { training stage }\end{array}$ & 1 week, 6 times & $\begin{array}{c}\text { Aerobic training with special } \\
\text { strength training }\end{array}$ \\
\hline $\begin{array}{c}\text { The third } \\
\text { training stagecial strength training and }\end{array}$ & 4 weeks, 6 times & $\begin{array}{c}\text { Start intensive training intensity } \\
\text { anaerobic training, and change } \\
\text { training methods flexibly }\end{array}$ \\
\hline Rest stage & 1 week, 3 times & $\begin{array}{c}\text { Reduce the training frequency and } \\
\text { intensity, relieve the sports fatigue }\end{array}$ \\
\hline
\end{tabular}

Table 1. Basic information of athletes.

\begin{tabular}{c|c|c|c|c|c|c|c}
\hline Gender & $\begin{array}{c}\text { Number } \\
\text { of } \\
\text { people }\end{array}$ & Age/year & Weight/kg & Height/cm & $\begin{array}{c}\text { Training } \\
\text { year Limit } \\
\text { /year }\end{array}$ & \multicolumn{2}{c}{ Competitive level } \\
\cline { 6 - 8 } & commonly & $\begin{array}{c}\text { high- } \\
\text { level }\end{array}$ \\
\hline Male & 10 & $22.32 \pm 1.22$ & $71.53 \pm 2.53$ & $172.64 \pm 2.49$ & $5.46 \pm 2.21$ & 5 & 5 \\
\hline Female & 10 & $22.25 \pm 1.29$ & $52.54 \pm 2.11$ & $161.2 \pm 2.52$ & $5.34 \pm 2.53$ & 5 & 5 \\
\hline
\end{tabular}


In order to achieve the test effect, it is necessary to collect blood on an empty stomach at each training stage of athletes, analyze immune cells by flow cytometry, and detect immune related factors in serum by indirect ELISA. At the same time, we should control the safety of the experiment, prevent the occurrence of adverse events, and formulate the corresponding emergency plan. Spss20.0 was used in this study, the measurement data was expressed by $( \pm s)$ and the test method was t-test; the unit was expressed in percentage, and the variance test was also conducted. When the test result $P<0.05$, it showed that the experimental results were meaningful.

\section{Experimental design and analysis}

For the whole evaluation system, coefficient of variation method can be used to calculate the weight of all primary indicators, and the results are 0.387 and 0.221 respectively. The weight of each subsystem and immunity index are weighted and summed to obtain the immunity model index of each stage, as shown in Table 3.

It can be seen from table 2 that the primary index subsystem in each stage is consistent with the total system in general, but there are differences in a few time periods, which can be divided into four stages: development, recession, recovery and stability. The level of humoral immunity (B1) in serum of volleyball players after taking exercise supplement containing anthocyanins is shown in Table $4 \sim$ table 5 .

It can be seen from the results that after the male and female athletes take the exercise supplement containing proanthocyanidins in each stage of training, the humoral immune indexes $\lg G$, IgA and IgM show an increasing trend, among which, the preparation and the first training stage do not show a strong trend, $P>0.05$; the second, third and after training are significantly strengthened, $P<0.05$, the main reason is that the training intensity is gradually increased, The difference was significant.

The level of cellular immunity (B2) of volleyball players in the experiment after taking sports supplements containing anthocyanins is shown in Table 6-7.

It can be seen from the results that the level of cellular immunity is similar to that of humoral immunity after taking exercise supplement containing proanthocyanidins in each stage of training, and each index of humoral immunity level shows an increasing trend. Among them, the preparation and the first training stage did not show a strong trend, $\mathrm{P}>$ 0.05 ; in the second stage, the training intensity was gradually increased, the cell immune level decreased significantly, $P<0.05$; in the third stage, the rest stage, the experimental training intensity of male and female

Table 3. Each stage of immunity index model.

\begin{tabular}{c|c|c|c|c|c}
\hline Year & $\begin{array}{c}\text { Preparation } \\
\text { stage }\end{array}$ & $\begin{array}{c}\text { The first } \\
\text { training phase }\end{array}$ & $\begin{array}{c}\text { The second } \\
\text { training stage }\end{array}$ & $\begin{array}{c}\text { The third } \\
\text { training stage }\end{array}$ & Rest stage \\
\hline$F X$ & 0.229 & 0.368 & 0.089 & -0.241 & 0.269 \\
\hline$F Y$ & 0.001 & 0.157 & 0.28 & 0.264 & 0.632 \\
\hline$F Z$ & 0.044 & 0.184 & 0.215 & 0.271 & 0.628 \\
\hline$F$ & 0.106 & 0.249 & 0.18 & 0.071 & 0.49 \\
\hline
\end{tabular}

Table 4. Changes of humoral immunity of male athletes.

\begin{tabular}{c|c|c|c|c|c}
\hline $\begin{array}{c}\text { Immune } \\
\text { index }\end{array}$ & $\begin{array}{c}\text { Preparation } \\
\text { stage }\end{array}$ & $\begin{array}{c}\text { The first } \\
\text { training phase }\end{array}$ & $\begin{array}{c}\text { The second } \\
\text { training stage }\end{array}$ & $\begin{array}{c}\text { The third } \\
\text { training stage }\end{array}$ & Rest stage \\
\hline $\lg \mathrm{M}$ & $1.28 \pm 0.55$ & $1.29 \pm 0.44$ & $1.33 \pm 0.38$ & $1.42 \pm 0.30$ & $1.56 \pm 0.40$ \\
\hline $\lg \mathrm{A}$ & $1.98 \pm 0.52$ & $2.02 \pm 0.39$ & $2.15 \pm 0.37$ & $2.26 \pm 0.52$ & $2.37 \pm 0.57$ \\
\hline $\lg \mathrm{g}$ & $1.05 \pm 1.06$ & $1.07 \pm 1.04$ & $1.30 \pm 1.13$ & $1.45 \pm 1.02$ & $1.70 \pm 1.22$ \\
\hline
\end{tabular}

Table 5. Changes of humoral immunity of female athletes.

\begin{tabular}{c|c|c|c|c|c}
\hline $\begin{array}{c}\text { Immune } \\
\text { index }\end{array}$ & $\begin{array}{c}\text { Preparation } \\
\text { stage }\end{array}$ & $\begin{array}{c}\text { The first } \\
\text { training phase }\end{array}$ & $\begin{array}{c}\text { The second } \\
\text { training stage }\end{array}$ & $\begin{array}{c}\text { The third } \\
\text { training stage }\end{array}$ & Rest stage \\
\hline $\lg M$ & $1.26 \pm 0.38$ & $1.29 \pm 0.28$ & $1.40 \pm 0.16$ & $1.46 \pm 0.18$ & $1.54 \pm 0.36$ \\
\hline $\lg A$ & $1.96 \pm 0.33$ & $1.99 \pm 0.19$ & $2.16 \pm 0.22$ & $2.24 \pm 0.25$ & $2.40 \pm 0.50$ \\
\hline $\lg G$ & $1.06 \pm 0.29$ & $1.09 \pm 0.24$ & $1.26 \pm 0.22$ & $1.36 \pm 0.23$ & $1.60 \pm 0.53$ \\
\hline
\end{tabular}

Table 6. Changes of cellular immunity in male athletes.

\begin{tabular}{c|c|c|c|c|c}
\hline $\begin{array}{c}\text { Immune } \\
\text { index }\end{array}$ & $\begin{array}{c}\text { Preparation } \\
\text { stage }\end{array}$ & $\begin{array}{c}\text { The first } \\
\text { training phase }\end{array}$ & $\begin{array}{c}\text { The second } \\
\text { training stage }\end{array}$ & $\begin{array}{c}\text { The third } \\
\text { training stage }\end{array}$ & $\begin{array}{c}\text { Rest } \\
\text { stage }\end{array}$ \\
\hline $\begin{array}{c}\text { White } \\
\text { blood cell }\end{array}$ & $7.32 \pm 1.13$ & $7.33 \pm 1.04$ & $7.13 \pm 1.08$ & $7.50 \pm 1.32$ & $7.69 \pm 1.08$ \\
\hline Neutrophils & $4.70 \pm 0.99$ & $4.72 \pm 0.90$ & $4.59 \pm 0.85$ & $4.84 \pm 0.83$ & $4.92 \pm 0.85$ \\
\hline lymphocyte & $2.10 \pm 0.29$ & $2.12 \pm 0.24$ & $2.02 \pm 0.22$ & $2.30 \pm 0.26$ & $2.36 \pm 0.28$ \\
\hline Monocyte & $0.40 \pm 0.08$ & $0.41 \pm 0.06$ & $0.25 \pm 0.05$ & $0.50 \pm 0.06$ & $0.59 \pm 0.13$ \\
\hline
\end{tabular}

Table 7. Changes of cellular immunity in female athletes.

\begin{tabular}{c|c|c|c|c|c}
\hline $\begin{array}{c}\text { Immune } \\
\text { index }\end{array}$ & $\begin{array}{c}\text { Preparation } \\
\text { stage }\end{array}$ & $\begin{array}{c}\text { The first } \\
\text { training phase }\end{array}$ & $\begin{array}{c}\text { The second } \\
\text { training stage }\end{array}$ & $\begin{array}{c}\text { The third } \\
\text { training stage }\end{array}$ & $\begin{array}{c}\text { Rest } \\
\text { stage }\end{array}$ \\
\hline $\begin{array}{c}\text { White } \\
\text { blood cell }\end{array}$ & $6.72 \pm 0.90$ & $6.76 \pm 0.92$ & $6.79 \pm 0.94$ & $6.82 \pm 0.80$ & $6.90 \pm 0.53$ \\
\hline Neutrophils & $4.22 \pm 0.88$ & $4.32 \pm 0.57$ & $4.50 \pm 0.48$ & $4.56 \pm 0.58$ & $4.67 \pm 0.83$ \\
\hline lymphocyte & $2.12 \pm 0.38$ & $2.29 \pm 0.27$ & $2.40 \pm 0.36$ & $2.68 \pm 0.33$ & $2.88 \pm 0.33$ \\
\hline Monocyte & $0.38 \pm 0.13$ & $0.42 \pm 0.14$ & $0.48 \pm 0.15$ & $0.52 \pm 0.14$ & $0.58 \pm 0.15$ \\
\hline
\end{tabular}

athletes decreased, and the cellular immune level was also significantly improved, $P<0.05$. In this experiment, no adverse reactions occurred in all subjects. Therefore, the results of this study show that the sports supplement containing proanthocyanidins has a certain degree of immune regulation in Volleyball Players' training of different intensities.

\section{CONCLUSION}

Based on the immunity level of grape proanthocyanidins sports supplements, taking volleyball students of XX Institute of physical education as an example, this study analyzed the immunity of volleyball players before and after taking grape procyanidins sports supplements. In the first and second stages of training, there was a trend of increasing the intensity of lgG in male and female athletes, but in the second stage, the results showed that the intensity of IgG was higher than 0.05 The level of cellular immunity was similar to that of humoral immunity, and the indexes of humoral immunity showed an increasing trend. Among them, the preparation and the first training stage did not show a strong trend, $P$ $>0.05$; in the second stage, the training intensity was gradually increased, the cell immune level decreased significantly, $\mathrm{P}<0.05$; in the third stage, the rest stage, the experimental training intensity of male and female athletes decreased, and the cellular immune level was also significantly improved, $P<0.05$. In this experiment, no adverse reactions occurred in all subjects. The results of this study show that the sports tonic containing proanthocyanidins has a certain degree of immune regulation in the training of volleyball players with different intensities. There are also some deficiencies in this study. In the future work, we will increase the factors that affect the level of athletes' immunity and construct the immune system.

All authors declare no potential conflict of interest related to this article

AUTHORS' CONTRIBUTIONS: The author has completed the writing of the article or the critical review of its knowledge content. This paper can be used as the final draft of the manuscript. Every author has made an important contribution to this manuscript. Mingang Guo: writing and execution. Xiaojun Tang: data analysis.

\section{REFERENCES}

1. Wu J, Huang W, Xiao H, Xie Y, Yuan Z, Yi J, et al. Procyanidins B2 reverses the T-2 toxin-induced mitochondria apoptosis in TM3 Leydig cells. Journal of Functional Foods. 2018; 45(12):118-128.

2. Sitong Z, Ligang Z, LuW. Total phenols, flavonoids, and procyanidins levels and total antioxidant activity of different Korean pine(Pinus koraiensis) varieties. Journal of Forestry Research. 2018; 30(12):1-12.

3. Masuda I, Koike M, Nakashima S, Mizutani Y, Ozawa Y, Watanabe K, et al. Apple procyanidins promote mitochondrial biogenesis and proteoglycan biosynthesis in chondrocytes. Sci Rep. 2018; 8(1):7229.

4. Shin YJ, Lee JH, Lee YK. Anti-Tumor Activity of Procyanidin and Its Effect on Hemocytes and Immunity. Journal of the Korean Society of Food Science and Nutrition. 2018; 47(10):966-972.

5. Satpati A, Subramanya M, Devi A, et al. Grape Seed Proanthocyanidin and Swimming Exercise
Protects Against Cognitive Decline: A Study on M1 Acetylcholine Receptors in Aging Male Rat Brain Neurochemical research. 2017; 42(3): 3573-3586.

6. Fei J, Qian C, Ping J. Protection of Grape Procyanidins against 60Co- $\gamma$ Radiation on Hematopoietic System of Mice. Pharm J Chin PLA. 2016; 032(004):335-337.

7. Fang L, Li M, Zhao L, Han S, LiY, Benhai X, et al. Dietary grape seed procyanidins suppressed weaning stress by improving antioxidant enzyme activity and mRNA expression in weanling piglets. Journal of Animal Physiology and Animal Nutrition. 2020; 104(4):1178-1185.

8. Peiyu Z, Lingmin Z, Wei L, Shuting Z, et al. In vitro evaluation of the anti-digestion and antioxidant effects of grape seed procyanidins according to their degrees of polymerization. Journal of Functional Foods. 2018;49(5):85-95. 